\title{
Trading death: the implications of annuity replication for the annuity puzzle, arbitrage, speculation and portfolios
}

Article

Accepted Version

Sutcliffe, C. (2015) Trading death: the implications of annuity replication for the annuity puzzle, arbitrage, speculation and portfolios. International Review of Financial Analysis, 38. pp. 163-174. ISSN 1057-5219 doi:

https://doi.org/10.1016/j.irfa.2014.10.010 Available at https://centaur.reading.ac.uk/37958/

It is advisable to refer to the publisher's version if you intend to cite from the work. See Guidance on citing.

To link to this article DOI: http://dx.doi.org/10.1016/j.irfa.2014.10.010

Publisher: Elsevier

All outputs in CentAUR are protected by Intellectual Property Rights law, including copyright law. Copyright and IPR is retained by the creators or other copyright holders. Terms and conditions for use of this material are defined in the End User Agreement.

www.reading.ac.uk/centaur 
Central Archive at the University of Reading

Reading's research outputs online 


\title{
Trading Death: The Implications of Annuity Replication for the Annuity Puzzle, Arbitrage, Speculation and Portfolios
}

\author{
Charles Sutcliffe*
}

3 October 2014

* The ICMA Centre, Henley Business School, University of Reading, PO Box 242, Reading, RG6 6BA.

Tel 0118-378-6117

email c.m.s.sutcliffe@,rdg.ac.uk

Thanks for comments on earlier drafts to an anonymous referee of this journal, and David Blake, Lars Bovenberg, Edmund Cannon, Martin Lehmann, Geng Li, Paula Lopes, Emmanouil Platanakis, Ian Tonks and participants in the $11^{\text {th }}$ International Workshop on Pensions, Insurance and Saving (Paris), the Netspar International Pension Workshop (Frankfurt) and a seminar at Reading University. 


\title{
Trading Death: The Implications of Annuity Replication for the Annuity Puzzle, Arbitrage, Speculation and Portfolios
}

\begin{abstract}
Annuities are perceived as being illiquid financial instruments, and this has limited their attractiveness to consumers and their inclusion in financial models. However, short positions in annuities can be replicated using life insurance and debt, permitting long positions in annuities to be offset, or short annuity positions to be created. The implications of this result for the annuity puzzle, arbitrage between the annuity and life insurance markets, and speculation on expected longevity are investigated. It is argued that annuity replication could help reduce the annuity puzzle, improve the price efficiency of annuity markets and promote the inclusion of annuities in household portfolios.
\end{abstract}

Keywords: Annuities, annuity puzzle, arbitrage, speculation, life insurance

JEL: G12, G22, G23 


\section{Introduction}

It is widely understood that annuities cannot be liquidated or traded, and so are highly illiquid assets. This paper explores the uses of a strategy to replicate a short annuity position which allows annuitants to fully or partially offset a long annuity position, in contradiction to the accepted view. The implications of this replication strategy for the well known annuity puzzle ${ }^{1}$, arbitrage between the annuity and life insurance markets, speculation on a change in an annuitant's longevity and constructing household portfolios are investigated. This is one of the first studies to conduct a detailed analysis of annuity replication and to investigate annuity arbitrage and longevity speculation. It also argues that annuity replication allows annuities to be integrated into the well-known models of mainstream finance, such as portfolio theory.

Section 2 explains how annuities are priced, section 3 covers the reasons for the illiquidity of annuities, and section 4 presents the relationship between the actuarially fair prices of annuities and life insurance. Section 5 shows how short positions in annuities can be replicated using life insurance and debt, and section 6 considers the implications of annuity replication for the annuity puzzle and argues that, by encouraging consumers to buy annuities, it could help solve this puzzle. Section 7 has a detailed analysis of annuity arbitrage, which is possible for annuity underpricings but not annuity overpricings. Examples are provided from a range of countries of situations where annuities have been substantially under-priced, followed by an examination of the effects of variations in annuity and life insurance load factors on arbitrage profits. This indicates that annuity arbitrage appears, on occasion, to be profitable. Section 8 demonstrates how annuity replication can be used to speculate on a change in an annuitant's expected longevity. The profits from such speculation are available in cash once the increase in expected longevity has been recognised. Section 9 argues that the ability to replicate short positions in annuities means that annuities can take a more prominent role in household portfolio decisions, and section 10 has the conclusions.

\section{Annuity Prices}

Annuity prices depend primarily on the expected longevity of the annuitant and interest rates expected over the remaining life of the annuitant. Annuity prices may also be affected by load factors such as

\footnotetext{
${ }^{1}$ The theory (Yaari, 1965, Davidoff, Brown and Diamond, 2005) indicates that consumers should annuitize most of their wealth, but actual rates of annuitization are much lower, and this widespread under-annuitization creates the annuity puzzle.
} 
adverse selection ${ }^{2}$, administration, regulatory and marketing costs, profit, the risk premium etc, but these effects are usually of modest size and exhibit only small variation over time. Studies for a range of countries have found the money's worth ratio (MWR) ${ }^{3}$ is usually not far below one and reasonably stable over time, James and Song (2001), James and Vittas (2000), Murthi, Orszag and Orszag (2000), Finkelstein and Poterba (2002), Cannon and Tonks (2004, 2008, 2009, 2011), and Von Gaudecker and Weber (2004). Therefore load factors are not of major importance, and the prices of annuities are determined primarily by longevity and interest rate expectations.

The actuarially fair price for a single premium, instantaneous, level, single life annuity in the absence of load factors is:-

$$
V_{x}=\sum_{i=1}^{n} \frac{A_{\cdot_{i}} P_{x}}{(1+r)^{i}}
$$

where $V_{x}$ is the current price or value of the annuity for an annuitant aged $x$ years.

$i$ is the number of years since the annuity was purchased

$r$ is the rate of interest for the remaining life of the annuitant (a non-stochastic interest rate with a flat term structure is assumed)

$A$ is the constant annual annuity payment

$n$ is a number greater than the remaining years of life of the annuitant

${ }_{i} P_{x}$ is the probability that an annuitant aged $x$ when the annuity was purchased survives for at least $i$ years.

As longevity expectations increase, annuity prices increase, while as interest rate expectations increase annuity prices decrease. The term ${ }_{i} P_{x}$ in equation (1) shows that the price of an annuity depends, not on the expected longevity, but on the cumulative probability distribution of expected longevity. Therefore, any change in the longevity distribution which alters the values of ${ }_{i} P_{x}$ will affect the annuity

\footnotetext{
${ }^{2}$ Those who subsequently have lives of above average length are more likely to buy annuities which produces adverse selection against the insurance company. In response insurance companies raise their prices to offset the effects of adverse selection.

${ }^{3}$ The MWR is the present value of the expected annuity payments, divided by the price of the annuity. A MWR of one means that the annuity has an actuarially fair price. MWRs are based on the mortality table chosen by the insurance company, and the set of future interest rates used by the insurance company as discount factors.
} 
price. For example, it is possible that, although some values of $P_{x}$ drop, others rise, so that overall the annuity price rises.

\section{Illiquidity and Annuities}

In the $18^{\text {th }}$ and $19^{\text {th }}$ centuries speculators were allowed to purchase annuities on the lives of nominees, rather than on their own lives. This permitted wide-scale adverse selection against annuity providers as annuity prices did not reflect the nominee's age or gender. For example in the early 1770 s banks in Geneva created lists of Genevan young girls from families with a record of health and longevity who could serve as nominees. The preference was for girls between the ages of five and ten years who had survived smallpox (Velde and Weir, 1992). These annuities and the income they brought could be traded while the nominee remained alive. To reduce the opportunities for adverse selection, annuities can now only be purchased on the life of the annuitant, and cannot be surrendered back to the provider or traded. For example, if allowed, annuitants would seek to sell their annuity shortly before their death (Brown, 2002). Furthermore, the judgement in 1745 by Lord Chancellor Hardwicke in the case of Lawley $v$ Hooper made clear that annuities which could be redeemed or repurchased were likely to be classified as usurious loans (Comyn, 1834). Although UK laws against usury were repealed in 1854, this judgement created a situation in which annuity agreements did not contain redemption clauses. Ogborn and Wallas (1955) and Browne, Milevsky and Salisbury (2003) suggest that the current inability to surrender annuities is because insurance companies use annuity receipts to make long term illiquid investments.

Defined benefit pensions lead to an annuity supplied by the pension scheme. On retirement, members of UK defined benefit pension schemes can take up to $25 \%$ of the total value of their accrued pension liability (depending on the rules of the scheme) as a tax-free lump sum, with the remaining $75 \%$ taken as a pension. Subsequently, these annuities cannot be traded or liquidated, and so in this respect are comparable to annuities purchased from an insurance company. Similarly, many people have state pensions which cannot be traded or liquidated, and so face the same illiquidity problems ${ }^{4}$. Therefore, due to defined benefit pensions, state pensions and defined contribution pensions taken before April 2015, part of the wealth of most people is tied up in an annuity that cannot be liquidated or traded.

\footnotetext{
${ }^{4}$ Until April 2015 at least $75 \%$ of UK defined contribution pension pots had to be used to buy an annuity before the age of 75 (although some exceptions existed) As from April 2015 the 2014 UK budget removed any compulsion for members of defined contribution schemes to buy an annuity.
} 
Annuitants cannot borrow using their annuity payments as collateral as annuity payments are conditional on the annuitant being alive. Nor can they assign the right to receive annuity payments.

\section{The Relationship Between Annuity and Life Insurance Prices}

There is a widespread view that annuities cannot be reversed, and so are illiquid assets, which discourages their purchase. However, given various assumptions, it is possible to replicate the cash flows of a short position in an annuity, and so effectively offset or liquidate an annuity. The strategy for replicating annuities relies on the relationship between the prices of annuities and life insurance. The purchaser of an annuity makes a large initial payment, and then receives a stream of payments until death, while the purchaser of life insurance makes a stream of life insurance premia payments until their death, at which time their estate receives a large terminal payment ${ }^{5}$. So, apart from the large payment being made at the end rather than the start, the pattern of cash flows of a life insurance policy is the inverse of those of an annuity.

Ignoring load factors, the actuarially fair price of life insurance (i.e. the annual life insurance premium, $Y)$ occurs when the following condition is met:-

$$
\sum_{i=1}^{n} \frac{{ }_{i} D_{x} X^{*}}{(1+r)^{i}}=\sum_{i=1}^{n} \frac{{ }_{i} P_{x} Y^{*}}{(1+r)^{i}}
$$

where $X^{*}$ is the sum insured, the * superscript denotes an actuarially fair price or amount, ${ }_{i} D_{x}$ is the probability that a person aged $x$ when the life insurance policy is purchased dies in year $i$, and

$\sum_{i=1}^{n} D_{x}=1$.

Insurance companies sell both life insurance policies and annuities, which has the advantage that the risks of these two types of business tend to be offsetting. For example, underestimating longevity means that annuities are underpriced, while life insurance is overpriced, Cox and Lin (2007). It is assumed that insurance companies use the same longevity estimates when pricing both life insurance and annuities ${ }^{6}$. Therefore, in a competitive environment with no load factors or other frictions, the

\footnotetext{
${ }^{5}$ This is pure life insurance with no savings component.

${ }^{6}$ The UK Continuous Mortality Investigation produces the mortality tables used by insurance companies for pricing both annuities and life insurance. If insurers choose to use unrealistically low forecasts of
} 
prices of both annuities and life insurance are driven to the prices in equations (1) and (2), and a fixed relationship exists between the prices of annuities and life insurance for policies on the life of the same person. For such actuarially fair prices with no load factors, this relationship is:-

$$
\overline{\mathrm{a}}_{\mathrm{x}}^{*}\left(\mathrm{y}_{\mathrm{x}}^{*}+\mathrm{r}\right)=1
$$

where $\bar{a}_{x}{ }^{*}$ is the actuarially fair cost today of an annuity of $£ 1$ for an annuitant aged $x$, and $y_{\mathrm{x}}{ }^{*}$ is the annual actuarially fair insurance premium for life insurance of $£ 1$ for an individual aged $x$, Milevsky (2006, pp. 145-6), Promislow (2011, pp. 69-70).

\section{Annuity Replication}

Yaari (1965), Bernheim (1991) and Brown (2001) have shown that debt and life insurance policies can be used to replicate a short annuity position. A long position in a level annuity ${ }^{7}$ can be offset by borrowing a sum of money now at a fixed rate of interest. At the same time the annuitant insures their life for an amount equal to the size of the loan. As demonstrated below, in the absence of load factors or other frictions the sum of the annual interest payments on the loan and the annual life insurance premia is equal to the annual annuity payments received, so the annuitant's net cash flow each year is zero. When the annuitant dies the life insurance payout is used to pay off the loan, and all payments cease.

The loan can be financed in two different ways. First, if the annuitant already has an investment in a fixed income security greater that the price of the annuity, e.g. a savings account, this money can be notionally borrowed and designated as a fixed rate loan to themselves. Alternatively, the annuitant can borrow the money externally, and this will probably lead to them paying a higher rate of interest than would an insurance company. For example, if the annuitant's interest rate is 50 basis points higher than the rate paid by an insurance company, the annuitant dies after 15 years, and the discount rate is 5\%; then the present value of the additional cost is $5.2 \%$ of the sum borrowed. When such an external loan is taken out the length of the loan period is unknown, as it depends on when the annuitant dies. Therefore a fixed rate long term loan may not be possible, and some interest rate risk will be involved

\footnotetext{
improvements in longevity for pricing life insurance, they are effectively imposing a load factor on life insurance. Although competitive forces will tend to eliminate such behaviour, to the extent it remains, it can be incorporated in the load factors considered below.

${ }^{7}$ Most annuities purchased from insurance companies are level and not index linked or escalating, although defined benefit and state pensions are index linked.
} 
in a variable rate loan. Any such interest rate risk could be hedged by, for example, investing an equivalent sum in a variable rate security, or by an interest rate swap. The lender will want collateral for the loan, and this could be achieved in two different ways. First there could be a mortgage on the annuitant's house or other assets. An alternative possibility is that the beneficiary of the life insurance policy agrees to act as guarantor of the loan. However, the annuitant may default on paying the life insurance premia and allow the policy to lapse, resulting in the guarantor being unable to honour the guarantee. To overcome this risk, the annuity provider could pay the life insurance premia direct to the life insurance company by deducting them from the annuity payments. This would be facilitated if the same company provided both the annuity and life insurance. Any additional costs generated when borrowing the money can be included with the load factors considered below.

Once the possibility of replicating annuities is recognised, financial services companies may offer advice and assistance to annuitants on offsetting their annuities and pensions. Such intermediaries would increase the knowledge of annuity replication amongst the general public, increasing the volume of such transactions. For example, in the UK financial intermediaries have recently sprung up to offer pension liberation to members under the age of 55, although the involvement of these intermediaries has led to mis-selling and fraud (Pension Regulator, 2013).

The market for life insurance for the elderly is thinner than for the young, but it is still possible to take out life insurance. For example, in the UK Aviva currently offers life insurance for those up to 80 years old. Insurers may fear adverse selection when the elderly buy life insurance, and for a sample of Americans with an average age of 56 years who bought life insurance, adverse selection was detected (Ho, 2009). However, using the same database, Cutler, Finkelstein and McGarry (2008) showed that those who insure their lives or buy annuities also take steps to avoid risk (e.g. avoiding dangerous occupations, not smoking, wearing seat belts, and engaging in preventative health care) resulting in lower mortality. This leads to advantageous selection in life insurance markets, even though there is adverse selection in annuity markets. In support of this view, Cawley and Philipson (1999) found no evidence of adverse selection for the US life insurance market.

If equation (3) is satisfied, the size of the loan (which is also the sum insured) can be set so that each year the sum of the interest and life insurance payments (assumed constant) are equal to the annual annuity payment. That is:- 


$$
\mathrm{A}=\mathrm{X}^{*} \mathrm{r}+\mathrm{Y}^{*}
$$

There are two reasons why the annuity payments are big enough to cover both the interest on the loan and the life insurance payments. First, the loan occurs at the start, while the payout on the life insurance policy occurs at the end. Second, the mortality credit ${ }^{8}$ means that the rate of return on the annuity exceeds the rate of return on a bond. If the current price of the annuity is equal to the loan (and sum insured) i.e. $V^{*}=X^{*}$, then, since $Y^{*}=y_{x}{ }^{*} X^{*}$ and $A=X^{*} / \bar{a}_{x}{ }^{*}$, equation (4) becomes $X^{*} / \bar{a}_{x}{ }^{*}=X^{*} r+y_{x}{ }^{*}$, or $\bar{a}_{x}{ }^{*}\left(y_{x}{ }^{*}+r\right)=1$, and so equation (4) is satisfied. Example 1 in appendix 1 shows how a short position in an annuity can be replicated so that it exactly offsets a long position in an annuity.

As well as using the relationship in equation (3) to replicate short positions in annuities, it can also be used to replicate short positions in life insurance. This is done by borrowing the money to buy an annuity, with the value of the annuity set using equation (4) so that the net cash flows cancel out. While it is possible to sell insurance policies in the US traded life settlement market, trading takes place at a deep discount, (Blake and Harrison, 2008, 2009; and Braun, Gatzert and Schmeiser, 2012), and the ability to offset life insurance may generate better prices for those who wish to cancel their life insurance. The UK has a well-developed market in life settlements, but this trades exclusively in traditional with-profits endowment contracts, i.e. traded endowment policies (Gatzert (2010), and so offsetting life insurance could be of interest to some people.

Charupat and Milevsky (2001) describe what they call a mortality swap, which involves buying both an annuity and life insurance at actuarially fair prices, where $V^{*}=X^{*}$. Then, by equation (4), this generates a riskless cash flow of $X^{*} r$ per year until the annuitant dies. So, while full replication generates a payment now $\left(X^{*}\right)$, a mortality swap produces a sequence of cash flows that continue for an uncertain period until the annuitant dies. Charupat and Milevsky (2001) show that, under Canadian tax laws, a mortality swap produces a tax gain.

Insurance companies usually include various costs (load factors) when pricing annuities. These include the insurer's overheads, such as administering the policies, marketing and compliance, as well as an allowance for profit, regulatory capital and any adverse selection. If life insurance or annuities are not

\footnotetext{
${ }^{8}$ The mortality credit is the reduction in the price of an annuity, relative to the cost of purchasing bonds, to give the same annual payment. This is due to the probability of death each year of the annuitant and the resulting cessation of the annuity payments. The higher is the probability of death, the greater is the mortality credit.
} 
traded at actuarially fair prices, equation (3) will not be met. Equation (4) still applies, but the value of the loan $(X)$ will no longer be equal to the current value of the annuity $(V)$ and there will be a gain or loss on the replication (or offset) of an annuity. If life assurance prices are above their actuarially fair price by $p$ percent, the size of the sum insured that satisfies equation (4) is given by equation (5), as demonstrated in examples 2 and 3 in appendix 2.

$$
\mathrm{X}=\mathrm{A} /\left[\mathrm{r}+\mathrm{y}_{\mathrm{x}}^{*}(1+\mathrm{p})\right]
$$

The profit $(\Pi)$ on annuity replication with load factors, where $w$ is the annuity load factor, is:-

$$
\Pi=\frac{A y_{x}{ }^{*}-Y^{*}(1+w)\left(r+y_{x}{ }^{*}(1+p)\right)}{y_{x}{ }^{*}\left[r+y_{x}{ }^{*}(1+p)\right]}
$$

When offsetting a previously purchased annuity, the load factor involved in its purchase is a sunk cost which can be ignored when making subsequent decisions, and only the life insurance load factor is relevant. The relationship between load factors and profit or loss is explored further in figure 2 in section 7 in connection with arbitrage.

\section{The Annuity Puzzle and Annuity Replication}

This section considers the effect of the ability to replicate short positions in annuities on the annuity puzzle. Yaari (1965) has shown that consumers can solve the dilemma of ensuring that they exhaust their resources on their last day of life by annuitizing all their wealth, with longevity risk passing from themselves to the annuity provider. This solves the household portfolio decision in favour of complete annuitization. Davidoff, Brown and Diamond (2005) have generalized Yaari's model and conclude that less than complete, although still substantial, annuitization is optimal. However, the actual level of annuitization is much lower than the total annuitization indicated by Yaari (1965), or the substantial levels of annuitization of Davidson, Brown and Diamond (2005), leading to the annuity puzzle.

A very wide range of explanations for the annuity puzzle have been proposed. Possible explanations include the load factor (including adverse selection), illiquidity, default risk, higher expected returns on equities, the unavailability of index linked annuities, small pension pots, the bequest motive, selfinsurance by families, taxation effects, behavioural effects, and biased estimates of longevity and interest rates. However, there is no widely accepted explanation of the annuity puzzle. 
One of the reasons that has been widely proposed to explain the annuity puzzle is that consumers are unwilling to buy annuities because they are illiquid irreversible contracts, Brown $(2002,2009)$, Brown and Warshawsky $(2004,2012)$. A UK survey of 3,511 people aged 50-64 years found that, of those who said they would never buy an annuity, $74 \%$ said this was because they would lose flexibility, which was the most popular reason by a considerable distance (Gardner and Wadsworth, 2004). In a US survey of 321 US financial planners, 31\% gave loss of flexibility and control as the reason for low annuitization. Again this response was far more popular than any other (Brown, 2002). A recent US survey by Beshears, Choi, Laibson, Madrian and Zeldes (forthcoming) found that flexibility in the timing of spending was the second most important factor in determining the choice between a lump sum and an annuity, after making sure of enough income in later life.

In the US the possibility of unexpected and substantial health expenses in old age creates a need for liquidity, and this militates against the purchase of annuities (Ameriks, Caplin, Laufer and Van Nieuwerburgh, 2008; Turra and Mitchell, 2008; Peijnenburg, Nijman and Werker, 2011; Park, 2011; Pang and Warshawsky, 2010; Nijman and Werker, 2011; and Sinclair and Smetters, 2004) 9 Peijnenburg, Nijman and Werker (2011) go so far as to argue that the possibility of unexpected heath costs early in retirement, coupled with the illiquidity of annuities, solves the annuity puzzle.

Sheshinski (2010) proposed the creation of refundable annuities which can be liquidated at a specified refund price, and so contain an embedded liquidation option. Wang and Young (2012a, 2012b) investigated the demand for what they call a commutable annuity, i.e. an annuity that can be surrendered to the supplier in exchange for a fixed proportion of its actuarially fair price at the time of surrender. They show that as the surrender charge increases, the level of annuitization is reduced, and suggest that the flexibility offered by commutable annuities may solve the annuity puzzle. Similarly Neuberger (2003) has argued that reversible annuities would help to solve the annuity puzzle. In contrast, Sinclair and Smetters (2004) conclude that, even if annuities were reversible and there are no transaction costs, the annuity puzzle remains.

The implications for the annuity puzzle of the strategy for replicating a short position in an annuity are unclear. Most annuity decisions are made by individuals, who are very clearly informed that the

\footnotetext{
${ }^{9}$ Health and long-term care insurance are ways of dealing with such contingencies.
} 
purchase of an annuity is irreversible. This is evidenced by the advice and promotional material received by potential annuitants ${ }^{10}$, and many academics have taken a similar position. If the advertized illiquidity of annuities is partly responsible for the annuity puzzle, awareness of the possibility of replication may increase annuity demand, going some way towards removing the annuity puzzle. However, the load factors for annuities and life insurance when replicating an annuity may be large enough to outweigh the desire for liquidity, removing the benefits of annuity replication and leaving the annuity puzzle unaffected.

Ameriks, Caplin, Laufer and Van Nieuwerburgh (2008) conclude that, if annuities could be liquidated or reversed at any time, this would lead to a substantial rise in demand, with an increase in the willingness to pay of up to $16 \%$. This suggests annuitants are willing to bear load factors of up to $16 \%$ in order to get liquid rather than illiquid annuities. Browne, Milevsky and Salisbury (2003) argue that, while investors differ in their personal circumstances and preferences, they might be willing to pay up to about $11 \%$ of the annuity price for a liquid annuity. Zeng (2010) found that when life insurance is not available to offset annuities, utility drops by up to $14 \%$. Therefore, if the load factors are less than about $11 \%-16 \%$, publicising the possibility of annuity replication may help to reduce the annuity puzzle.

Using US survey data Brown, Casey, and Mitchell (2007) found that when an annuity was priced at only $75 \%$ of its actuarially fair value, $37 \%$ of the subjects preferred to receive a lump sum equivalent to the actuarially fair annuity price, i.e. a $25 \%$ discount on the annuity was insufficient to make them prefer the annuity. The lump sum tended to be preferred by those who were unemployed, better educated and in poor health. When 20,000 teachers in Illinois were offered the opportunity to secure

10 "Once you've bought an annuity there's no going back, so you've got to get it right first time." Which? http://www.which.co.uk/money/retirement/guides/annuities-explained/buying-an-annuity/

"Once bought, they cannot be changed, transferred or cashed-in." The Annuity Bureau http://www.annuitybureau.co.uk/about-annuities/conventional-annuities.aspx

"You only have one opportunity to shop around for your annuity. Once you have committed to an annuity provider and started to receive an income, the decision can't be reversed." Age UK http://www.ageuk.org.uk/products/financial-products-and-services/annuities/

"Make the right decision now, because you cannot reverse it later". Nationwide http://www.nationwide.co.uk/investments/products and services/annuities/default.htm

"Buying an annuity is a long-term decision - once it's set up you can't cash it in or make any changes." Standard Life

http://www.standardlife.co.uk/1/site/uk/pensions/our-retirement-and-annuity-products/annuit y-compulsory-purchase 
additional pension benefits in exchange for a lump sum payment, the average amount they were prepared to pay was only $19 \%$ of the actuarially fair value; indicating that at the margin members placed a much higher value on cash now than on an annuity of equivalent actuarial value (Fitzpatrick, 2011).

Brown, Kapteyn, Luttmer and Mitchell (2013) used a sample of 2,210 US households to study their willingness to reduce their Social Security payments in return for a lump sum payment. The actuarially fair value of the Social Security payments that were hypothetically liquidated was $\$ 16,855$, while the median compensation required by respondents was only $\$ 13,750$, i.e. a discount of $18 \%$. There was substantial dispersion in these valuations, with $5 \%$ of the sample willing to accept a discount of $91 \%$ to liquidate their annuity. These results indicate considerable scope for annuitants being willing to offset their annuities at very low MWRs.

When they retire members of UK defined benefit schemes can exchange up to $25 \%$ of their pension for a tax-free lump sum. Lump sums are popular and the take-up is high. The rate of exchange is the relevant commutation factor set by the pension scheme. Commuting part of a pension for a lump sum is the opposite of buying an annuity, with the price given by the commutation factor. Surveys of UK commutation factors have been conducted by the Government Actuary, the National Association of Pension Funds and the Pensions Board (Pensions Board, 2006). They found commutation factors typically varied between $£ 9$ and $£ 16$ of the tax free lump sum per $£ 1$ of pension. The Pensions Board study concluded that "most schemes provide cash commutation terms substantially lower that the cost of purchasing an annuity", and so many annuitants are willing to offset the first $25 \%$ of their annuities at markedly unfavourable rates ${ }^{11}$.

If the apparent illiquidity of annuities is not the reason for the annuity puzzle, removing this perceived restriction will have no effect on the demand for annuities. It is also possible that annuity replication could lead to the effective (or net) rate of annuitization being overstated. Those who have a defined

\footnotetext{
${ }^{11}$ The tax benefit of the lump sum depends on the annuitant's marginal tax rate in retirement. For pensioners paying the basic tax rate of $20 \%$, given the low commutation rates, the tax free lump sum has a lower present value that the annuity. Depending on the commutation rate used by their scheme, this may also be the case for those subject to the higher tax rate of $40 \%$ in retirement. If annuitants wish to offset a higher percentage of their annuity, as from April 2015 annuitants must pay tax on the excess at their marginal tax rate. Conversely, if an annuity is not offset, the annuitant must pay tax on the annuity payments when they are received, and so the remaining $75 \%$ of an annuity is taxed either way.
} 
benefit pension, state pension or defined contribution pension may decide to offset part or all of these pensions. The pensions will still be paid, and so appear in the statistics, but the economic reality will be that, due to annuity replication, those who fully offset their pensions will no longer have an annuity.

A number of empirical studies using US data have examined the extent to which annuities are offset. There are various reasons why a household may simultaneously hold long positions in both annuities and life insurance, i.e. an annuity offset position:- (a) to remove the drop in wealth suffered by a surviving spouse when an annuity on the life of their deceased spouse ceases (Auerbach and Kotlikoff, 1987, 1989), (b) to provide a bequest by converting an annuity into a lump sum (Bernheim, 1991, Brown 2001), (c) to reallocate consumption across time in a way that is incompatible with the income stream from their annuity, (d) to offset an annuity to create a precautionary balance to meet unexpected expenditure shocks, e.g. health expenses, (e) to provide a ready source of funds to their executors to cover their funeral expenses, and (f) because they continue to hold life insurance when it is no longer required to insure their future earning potential after they have retired (Brown, 2001).

Auerbach and Kotlikoff $(1987,1989)$ examined the purchase of insurance on the life of a spouse with an annuity income, with the surviving spouse as the beneficiary of the life insurance. Such life insurance is designed to ensure there is no drop in the survivor's consumption after the death of their spouse. However Auerbach and Kotlikoff were unable to find evidence of such behaviour in the US. Bernheim (1991) and Brown (2001) investigated the extent to which US pensioners use life insurance to offset state pensions (i.e. annuities) in order to leave bequests. In Bernheim's sample $36 \%$ were both in receipt of an annuity and had life insurance. He found evidence that about a quarter of US pensioners were over-annuitized and offset roughly $20 \%$ of their annuities. Brown (2001) argues that this result may be attributable to data problems. Using different US data Brown (2001) concludes that no more than $2 \%$ of his sample had bought life insurance to offset annuities in order to provide for a bequest motive. Empirical investigations of annuity replication using US data have looked for offset amongst married couples, and offset to generate a bequest, but there have been no studies looking for offset due to reallocating consumption, a precautionary motive, provision for funeral expenses or inertia. In addition, as explained below, annuity replication can be used for arbitrage and speculation, but there have been no empirical studies of these additional motives for annuity replication.

\section{Arbitrage and Annuity Replication}


Arbitrage involves the simultaneous purchase of one asset against the sale of the same or equivalent asset from zero initial wealth to create a riskless profit due to price discrepancies. A short position in an annuity can be replicated using life insurance and debt, while long positions in annuities can be purchased in the market. Therefore if annuities are underpriced arbitrage is possible. Example 4 in appendix 3 shows how an annuity underpricing can be arbitraged when there are actuarially fair life insurance prices, and example 5 in appendix 3 demonstrates arbitrage when life insurance is overpriced.

Due to the presence of load factors, annuity prices tend to be above the actuarially fair price. Life insurance has a similar set of costs, leading to life insurance prices tending to be above the actuarially fair price. When annuities are overpriced, arbitrage is not possible because individuals cannot sell annuities or life insurance. However the inability to arbitrage overpricings does not necessarily mean annuity prices fail to reflect the no-arbitrage condition in equation (3). Annuity overpricings, or life insurance underpricings, can be removed by competition between insurance companies, with consumers choosing to buy annuities and life insurance from the cheapest supplier, or deciding not to purchase an annuity or life insurance.

There are three ways of presenting annuity prices $^{12}$ : (a) the sum that must be paid by the annuitant to buy an annuity of a specified size $(V)$, e.g. $£ 100,008$ for an annuity of $£ 8,245$ p.a., (b) the MWR, which is the actuarially fair price divided by the actual price $\left(\bar{a}_{x}^{*} A / V\right)$, and (c) the annuity rate, i.e. $(A / V)$. Annuity prices are usually presented as annuity rates, but for arbitrage purposes the price of the annuity $(V)$ is preferable. If the annuity price is less than the actuarially fair annuity price $\left(\bar{a}_{x}^{*} A\right)$ there is a mispricing that is potentially arbitrageable. Arbitrage is only profitable if the mispricing is large enough to cover the load factors of both the annuity $(L F A)$ and the life insurance $(L F L)$. So an arbitrage opportunity only exists if:-

$$
\overline{\mathrm{a}}_{\mathrm{x}}^{*} \mathrm{~A}>\mathrm{V}+\mathrm{LFA}+\mathrm{LFL}
$$

Figure 1 shows the actuarially fair price $\left(\mathrm{AF}\right.$, or $\left.\bar{a}_{x}^{*} A\right)$, and the no-arbitrage boundary (NAB, or $\left.\bar{a}_{x}^{*} A-L F A-L F L\right)$. Values of $V$ below the NAB line represent arbitrage opportunities (i.e. inequality (7) is satisfied), while values of $V$ between the $\mathrm{AF}$ and $\mathrm{NAB}$ lines are underpricings. However, inequality (7) is not met, and so they are not arbitrage opportunities. For annuity overpricings, competition between insurance companies will tend to push annuity prices down to cost, which is an overpricing

\footnotetext{
${ }^{12}$ Annuity equivalent wealth will not be considered as it requires knowledge of the annuitant's utility function (Mitchell, Poterba, Warshawsky \& Brown, 1999).
} 
of $\bar{a}_{x}^{*} A+L F A$ and shown as the competitive boundary

line $(\mathrm{CB})$ in figure 1 . In the zone between the $\mathrm{CB}$ and

NAB lines where arbitrage does not operate, as well $\mathrm{V}$ as below the NAB line, competition in the annuity market will tend to push prices up to the CB line, which represents zero abnormal profit for insurance companies. The distance between $\mathrm{CB}$ and $\mathrm{AF}$ in priced figure 1 is less than that between $\mathrm{AF}$ and $\mathrm{NAB}$ because arbitrage involves both the annuity and insurance load factors, while $\mathrm{CB}$ includes only the $\mathrm{CB}$ is the competitive boundary, $\mathrm{AF}$ is the annuity load factors.

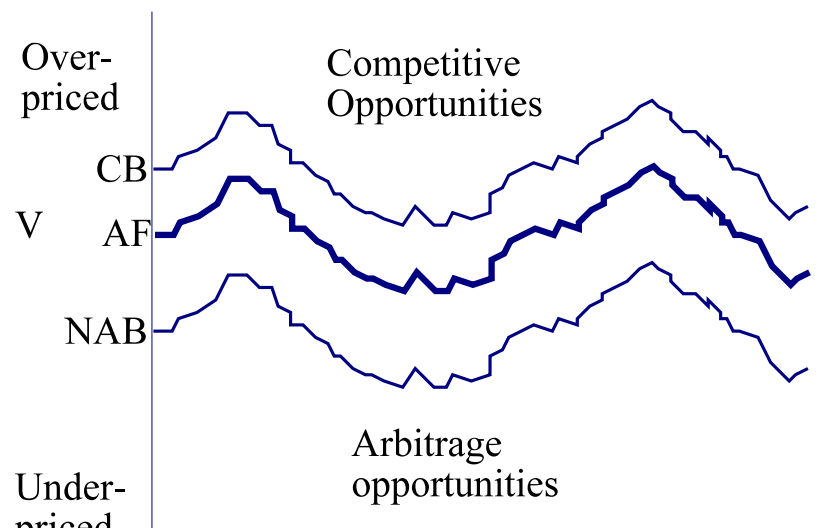

Time

Figure 1: Arbitrage of Underpricings actuarially fair price and NAB is the no arbitrage boundary. Arbitrage will push annuity prices up to $\mathrm{NAB}$, while competition will push prices up or down to $\mathrm{CB}$.

If insurance companies price annuities at their actuarially fair level, and then add competitive load factors, annuity prices will tend to fluctuate around the cost boundary line $(\mathrm{CB})$ in figure 1 . Therefore prices below the NAB line, i.e. arbitrage opportunities, are likely to be rare. However, there are occasions when annuities are substantially underpriced, relative to the actuarially fair price. For example, the Oregon Public Employees Retirement System offers annuities with a median MWR of 1.45 (and over 1.60 in more recent years), which is an underpricing of $(0.45 / 1.45)=31 \%$ (and in some years over 38\%), Chalmers and Reuter (2012). This underpricing is very probably large enough to be an arbitrageable. The purchase of these annuities is restricted to retiring members of this pension scheme, and it is surprising that only $85 \%$ of members on average opt for the annuity, with the remaining $15 \%$ (about 4,800 people) choosing the lump sum ${ }^{13}$.

Previous researchers have computed the MWR for various years and a range of annuities in different countries, and a few of these ratios are substantially above one. Fong, Mitchell and Koh (2010) estimated that in Singapore the MWR for CPF LIFE (refund 75) annuities in 2008 was 1.37 for women and 1.34 for men, while James and Vittas (2000) computed a MWR in Singapore for both men and women of 1.25. For Chile, Rocha and Thorburn (2007) and Thorburn, Rocha and Morales (2007) report that for the years 2002-2005 almost all annuities had a MWR above one, with some annuities having MWRs of 1.28. One MWR in India for 2002 was 1.25 (James and Sane, 2003). Bütler and Staubli

\footnotetext{
${ }^{13}$ The perceived lack of liquidity of annuities or lack of knowledge of annuity replication may have deterred this $15 \%$.
} 
(2011) computed a MWR of 1.31 for Swiss women, and 1.32 for married Swiss men in 2009, while Bütler and Ruesch (2007) found MWRs of 1.475 for unmarried Swiss women in 2003 and 1.440 for married Swiss men in 2005. James and Song (2001) document a MWR of 1.20 for joint life annuities in Switzerland, while James and Vittas (2000) report Swiss MWRs of 1.17 for men and 1.15 for women. They also found MWRs of 1.16 for Israeli men and 1.24 for Israeli women. For Canadian men, Milevsky and Shao (2011) found a MWR that approached 1.20 in 2009. Von Gaudecker and Weber (2004) computed a MWR of 1.10 for German men, while Kaschützke and Maurer (2011) found MWRs of over 1.20 in 1999 for German men and women. Cannon and Tonks (2004) have estimated that the MWRs for UK males in 1971, 1990 and 1991 were above 1.20. Finally, Mitchell (2002) found a MWR of 1.14 for US Hispanic women in 1998. These studies show that, while substantial annuity underpricing is uncommon, it does happen, and arbitrage opportunities can sometimes occur.

There is empirical evidence to support the view that annuity prices do not immediately respond to changes in the main factors determining annuity prices, indicating a market that is inefficient at the semi-strong level. Charupat, Kamstra and Milevsky (2012) studied the speed of response of US annuity prices to changes in interest rates, and found that the response takes several weeks. There is also crosssection evidence of considerable price dispersion. In 2009 a comparison of the prices for annuities in the UK found that a top quartile annuity was $20 \%$ cheaper than a bottom quartile annuity ((MGM Advantage, 2009), while Harrison, Byrne and Blake (2006) report that the differential between the highest and lowest UK prices can be up to 39\%. Crawford and Tetlow (2012) found a 17\% price improvement for those who purchased externally, rather than accepting an annuity from their pension provider. Hueler and Rappaport (2012) analysed US annuity prices and found the average difference between the high and low prices was $8 \%$, although in some cases this difference was $20 \%$. These findings indicate that price competition and the effects of arbitrage in the annuity market are weak.

Such variation in annuity prices between suppliers makes arbitrage more likely to be profitable because arbitrageurs can buy from the cheapest supplier. However, arbitrage opportunities in the annuity market are unlikely to be immediately removed in the way that occurs in other financial markets. Arbitrage can be of an unlimited scale in other financial markets, and so a few very wealthy arbitrageurs (e.g. investment banks or hedge funds) are able to remove any arbitrage opportunities. Annuity replication can only be undertaken by individuals on their own lives, and so many arbitrageurs are needed to move prices. 
To investigate the relationship between load factors and arbitrage profit, equation (6) was used to compute the profit or loss from arbitrage for various combinations of annuity and life insurance load factors. Figure 2 shows the isoprofit curves, which are convex to the origin, for various combinations of annuity and life insurance load factors. The arrow in figure 2 shows the direction of increasing arbitrage profit. The area in the north west quadrant below the

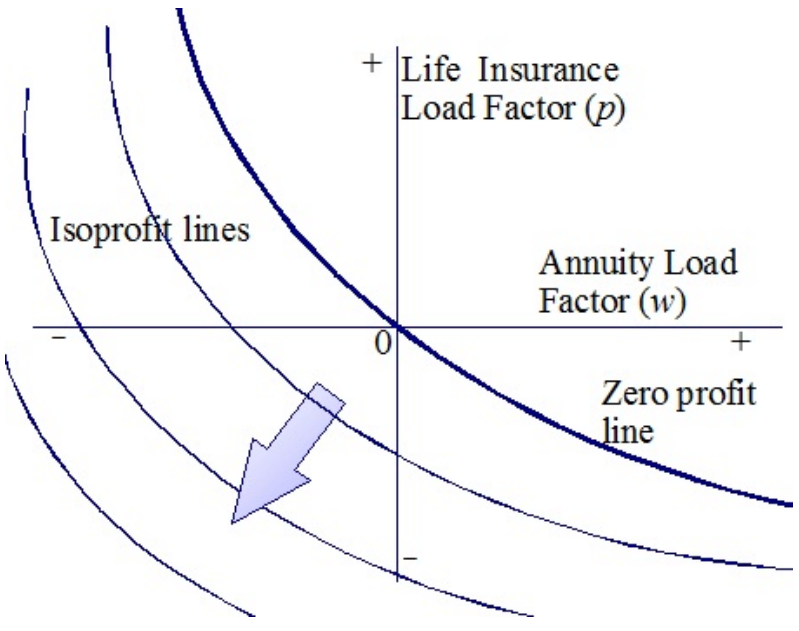

Figure 2: Arbitrage Profit zero profit line shows that arbitrage profits are Isoprofit curves for arbitrage between the annuity possible when there is a positive life insurance load and life insurance markets allowing for various load factors factor, and the area in the south east quadrant below the zero profit line shows that arbitrage profits are available when there is a positive annuity load factor.

Differentiating equation (6) with respect to the annuity load factor $(w)$ reveals that a $1 \%$ increase in $w$ leads to a reduction in the arbitrage profit of $1 \%$ of the sum insured when there are actuarially fair prices $\left(X^{*}\right)$, irrespective of the life insurance load factor $(p)$.

$$
\partial \Pi / \partial \mathrm{w}=\mathrm{X}^{*}
$$

Differentiating equation (6) with respect to the life insurance load factor ( $p$ ) gives:-

$$
\frac{\partial \Pi}{\partial p}=\frac{-A y_{x}^{{ }^{*} 3}}{\left(y_{x}{ }^{*} r+y_{x}{ }^{* 2}(1+p)\right)^{2}}
$$

Equation (9) reveals that the arbitrage profit is a non-linear function of the life insurance load factor; and that this relationship depends on the parameters $A, y_{x}{ }^{*}, r$ and $p$, but not the annuity load factor $(w)$. Overall, the analysis in this section suggests that, given the assumptions made previously, arbitrage opportunities sometimes occur in annuity markets ${ }^{14}$.

\section{Longevity Speculation and Annuity Replication}

There is evidence that potential purchasers of annuities and life insurance possess much better information about their own life expectancy than do insurance companies. This information asymmetry

\footnotetext{
${ }^{14}$ Arbitrage may also be possible for those who are not yet receiving an annuity using the prices of deferred annuities and deferred life insurance policies.
} 
leads to adverse selection in annuity markets, Finkelstein and Poterba (2002, 2004), Fong (2002), Friedman and Warshawsky (1990), Mitchell and McCarthy (2002), and Walliser (2000) ${ }^{15}$.

Not only do annuitants have better information on their life expectancy when they buy an annuity or life insurance (Idler and Benyamini, 1997), but they are more likely to be aware of changes in their life expectancy that occur after the annuity or life insurance has started. Insurance companies only assess annuitants' life expectancy when the annuity or life insurance is purchased as the payments remain fixed once the contract is traded, and so they are unaware of later changes in health status and life expectancy. This information asymmetry offers an opportunity for consumers to benefit from subsequent changes in their life expectancy ${ }^{16}$. Speculators, who are assumed to already hold their desired stock of annuities, can buy or sell (via replication) an annuity in the expectation that their life expectancy, as assessed by insurance companies, will rise or fall in the future.

Keilman (2007) investigated the accuracy of male longevity forecasts made by official agencies for 14 European countries over the period 1950 to 2001 . He found longevity forecasts 26 years ahead consistently under-predicted actual longevity by almost five years (a 19\% error). Shaw (2007) obtained similar results for the UK. This shows that, for the male population as a whole, longevity forecasts have been substantially below actual longevity. For many individuals the longevity under-prediction will have been even larger, indicating plenty of scope for speculation on upward revisions in longevity expectations.

Insurance companies assess the annuitant's life expectancy using a variety of pieces of information such as age, gender, post code, health status, occupation, marital status, education, size of the annuitant's pension pot and behavioural risks (Fong, 2011, Brown and Scahill, 2010, Brown and McDaid, 2003)). The criteria used vary both over time and between insurance companies. The expected longevity of an annuitant, as assessed by insurance companies, may increase for a variety of reasons ${ }^{17}$. For example,

\footnotetext{
${ }^{15}$ The evidence for adverse selection in life insurance markets is mixed - Cawley and Philipson (1999), Cutler, Finkelstein and McGarry (2008), He (2009), McCarthy and Mitchell (2010).

${ }^{16}$ It is possible for US annuitants to speculate on a drop in longevity expectations using just life insurance. This can be done by buying life insurance, and then waiting for longevity expectations to drop before selling their policy in the traded life settlement market. However, this market trades at a deep discount.
}

${ }^{17}$ Reversing these arguments provides reasons for a decrease in expected longevity. 
consumers may expect that new mortality tables will show a rise in longevity for their gender and age cohort, or that there will be a substantial change in the nature of those living in their post code due to an influx of people with greater longevity than the current residents. They may plan to move to a post code where the residents have a greater longevity than their current post code, or to switch to a lower risk occupation. They might intend to give up smoking, lose weight or otherwise change their behaviour in a way that increases their expected longevity, or they may have previously undergone genetic testing (whose results they are not required to disclose to the insurance company) which reveals that their longevity is higher than expected, and then choose to disclose this information when they buy life insurance.

Speculators may expect that estimates of the life shortening effects of their medical condition will be revised downwards due to new medical evidence or treatment, or that they will recover from a lifeshortening medical condition, so increasing their expected longevity. For example, they may have been assessed as having a high probability of death in (say) the two years after they bought the annuity, but if they survive this period their expected longevity greatly increases, e.g. the cancer treatment has worked. When they buy the annuity the annuitant may have information that, in their particular case, the treatment is more likely to be successful than the figure used by insurance companies.

The size of an annuitant's pension pot is used by some insurance companies when setting annuity rates, and the speculator may expect that the size effect on annuity rates for a pot of their size may change, leading to an increase in the annuity price. They may predict that the criteria used by insurance companies change in a way that increases the annuitant's expected longevity. For example Fong (2011) shows that using marital status and education would improve longevity prediction in the US. Annuitants might be planning to undergo gender reassignment from male to female, or expect that annuity and life insurance prices will be legally required to be gender neutral (as in the European Union), so benefiting female annuitants ${ }^{18}$.

If an individual wishes to speculate on an increase in their expected longevity, as assessed by insurance

\footnotetext{
${ }^{18}$ UK annuity and life insurance prices were required to be unisex as from 21 December 2012 by a ruling of the European Court of Justice on $1^{\text {st }}$ March 2011. This ruling does not apply to occupational pensions.
} 
companies, this can be accomplished by purchasing an annuity ${ }^{19}$, which involves both longevity and interest rate risk. The speculator hedges the interest rate risk implicit in the annuity, leaving the longevity risk. Example 6 in appendix 4 demonstrates how a speculator can make a profit if their longevity increases, and enjoy the profit when the increase in longevity is recognized by an insurance company. The speculator can buy the annuity from the insurance company with the lowest longevity expectations at that time. Later, when they buy life insurance to offset the annuity, they can buy from the insurance company which then has the highest longevity expectations.

A potential speculator may already own an annuity due to being a member of a defined benefit or defined contribution pension scheme, have a state pension, or have voluntarily purchased an annuity, and be content with their current holding of annuities. They may now realise that insurance company expectations of their longevity have risen, thereby increasing the value of these annuities and their wealth. While they could offset some of their annuities and convert this gain into cash, the increase in their longevity means they now expect to have to support themselves for additional years of life. Therefore, along with the additional wealth comes an offsetting liability. Their response to this situation depends on their preferences, and they may decide not to offset any of their holdings of annuities.

Since life insurance and debt can be used to replicate a short position in an annuity, it is possible to use annuity replication to speculate on a decrease in expected longevity. This is done by buying life insurance and borrowing the sum insured to create a synthetic short position in an annuity. At the same time the interest rate risk of this synthetic short annuity position is hedged. When annuity prices have declined along with longevity expectations, an annuity is purchased at a favourable price, the interest rate hedge is closed, and the speculation is effectively ended (see example 7 in appendix 5).

Individuals can also speculate on a rise in their longevity by buying an annuity (and hedging the interest rate risk), and then living beyond its break-even age, rather than offsetting the annuity. The resulting gain is only available after the annuitant passes the annuity's break-even age, with the additional annuity payments being received during the final years of the annuitant's life. These payments depend on how long they actually live, rather than their expected longevity when the annuity is purchased, and so are risky. An individual can also speculate on a fall in their longevity by insuring their life (and

\footnotetext{
${ }^{19}$ If the individual already has an annuity, unless this person wishes to retain their initial annuity, the
} annuity load factor is a sunk cost. 
hedging the interest rate risk), and then dying soon afterwards, rather than offsetting their life insurance. In this case their estate, rather than themselves, will benefit from the early payout of the death benefit.

An individual who is not retired may anticipate a rise (fall) in their expected longevity during the period before they retire. They can speculate on such a rise (fall) by buying a single premium deferred annuity (buying a deferred life insurance policy) coupled with an interest rate hedge. This locks in the annuity or life insurance price now using current longevity expectations. There is an extra risk in such trades as the speculator needs to forecast the size of the annuity or pension they will receive on retirement.

Longevity speculation requires the speculator to have access to the capital to buy an annuity and be able to borrow the sum insured. Speculators are also exposed to longevity expectations risk, as well as incurring various transactions costs. So any profits have to be balanced against the transactions costs, risks and cost of capital. As with most speculative trades, the speculator also has the problem of deciding when to take their profit, or cut their losses. In this case the problem may be slightly easier as the speculation might be on some discrete event, such as a change in policy by insurance companies, the release of new mortality data, or a change in the status of the annuitant.

\section{Portfolios and Annuity Replication}

The ability to replicate short positions in annuities has important implications for household portfolio decisions, as a substantial part of household wealth is invested in annuities. For example, in 2010 total UK pension liabilities were $£ 7$ trillion, or almost five times UK gross domestic product (OECD, 2012). Since households have a large proportion of their wealth in annuities, household portfolio models need to incorporate investment in annuities. Longevity risk is a primary driver of the demand for annuities, and so the incorporation of annuities in portfolio problems leads to multi-period life cycle portfolio models. The ability to replicate short positions in annuities means they can be treated like other financial assets that can be both purchased and liquidated, and this facilitates their inclusion in portfolio models. Since short positions in annuities can be replicated, models incorporating annuities need not impose a restriction on short sales, although this non-negativity restriction is common in portfolio models. A few researchers have investigated such portfolio models and included investment in irreversible annuities, along with equities and bonds in multi-period portfolio models ${ }^{20}$. However the

${ }^{20}$ Babbel and Merrill (2007), Gupta and Li (2007), Horneff and Maurer (2008), Horneff, Maurer, Mitchell and Dus (2008), Horneff, Maurer, Mitchell and Stamos (2009, 2010), Horneff, Maurer and 
vast majority of portfolio models do not include annuities as an existing or potential investment, and a recent survey of household finance mentions annuities only in a footnote and appendix (Guiso and Sodini, 2013).

\section{Conclusions}

Annuities are generally viewed as irreversible investments, and this perceived illiquidity may be partly responsible for their neglect by both consumers and finance researchers. This paper has shown that annuities can be treated as liquid financial instruments, and demonstrated how they can be integrated into some standard finance models. Because of the relationship between annuity and life insurance prices, short positions in annuities can be replicated using life insurance and debt. This enables long positions in annuities to be offset, which considerably increases their liquidity. Using this relationship, it is also possible to offset long positions in life insurance. Widespread knowledge of the possibility of annuity offset should increase the willingness of households to buy annuities, in the knowledge that it is not an irreversible position, and this may help to reduce the annuity puzzle. This view is supported by evidence of the demand to offset annuities at prices well below the actuarially fair price.

The inefficiency of annuity markets offers scope for arbitrage between the life insurance and annuity markets, and for speculation on the expected longevity of annuitants. The ability to replicate short annuity positions permits the arbitrage of annuity underpricings, and knowledge of how to conduct such arbitrage should increase the low price efficiency of annuity markets. It has been demonstrated that, subject to a number of assumptions, arbitrage may sometimes be profitable, even when substantial load factors and other frictions are present. A long annuity position gives the owner an embedded American style option to liquidate this annuity at a better price sometime in the future, and this permits individuals to speculate on changes in their own life expectancy. Arbitrage and speculation using annuities can only be conducted by the annuitant, as annuities must be purchased by the nominee. So the size of individual arbitrage and speculative transactions is severely limited. Arbitrage and longevity speculation also incur greater load factors and frictions than when offsetting an existing annuity.

Annuity replication is subject to a range of real world frictions such as the inability of individuals to borrow on the same terms as insurance companies, different longevity estimates for pricing annuities

Rogalla (2010), Horneff, Maurer and Stamos (2008a, 2008b), Huang and Milevsky (2008), Kapur and Orszag (1999), Milevsky and Young (2007) and Pang and Warshawsky (2010). 
and life insurance, and tax effects; as well as the usually load factors and the need for annuitants to be financially sophisticated enough to execute the replication strategy. However, the evidence is that some annuitants are willing to liquidate annuities at very considerable discounts, opening up the possibility of a limited amount of annuity offsetting; although the frictions may be too great at the moment to make arbitrage and speculation worthwhile.

Households typically hold a sizable proportion of their wealth as long positions in occupational and state pensions and annuities. Given the importance of annuities, recognition of the ability to liquidate these positions facilitates their incorporation in household portfolio models, as additional annuities can be purchased, existing annuities offset, or short positions created. The inclusion of annuities in household portfolio models also highlights the need to use multi-period life-cycle portfolio models for households.

Given the apparent demand for annuities which can be liquidated, insurers may decide to offer such products $^{21}$. The cash refund might be set by reference to the cost of replicating a short position in the annuity at the time of its liquidation, less some redemption charge. The 2014 UK budget removed compulsory annuitization $^{22}$ for those with defined contribution pensions, and those with private sector defined benefit pensions can transfer their pension to a defined contribution scheme shortly before retirement, thereby avoiding compulsory annuitization. So the UK political climate has recently become favourable to the liquidation of annuities, and financial service companies may choose to offer a service to help annuitants offset unwanted annuities.

\section{References}

Ameriks, J., Caplin, A., Laufer, S. and Van Nieuwerburgh, S. (2008) Annuity Valuation, Long Term Care and Bequest Motives. In Recalibrating Retirement Spending and Saving edited by J. Ameriks and O.S. Mitchell, Oxford University Press, pp. 251-275.

\footnotetext{
${ }^{21}$ Following the 2014 UK budget, Partnership introduced an enhanced choice annuity. This lifetime annuity has an embedded European style option which allows the annuitant to liquidate the annuity one year after purchase.

${ }^{22}$ Compulsion has the advantage that it ensures there is no adverse selection in the market for compulsory annuities, and this reduces annuity prices. Compulsion also avoids the moral hazard that pensioners will spend all their pension pot, and then fall back on the welfare state. Pension pots have been accumulated without paying tax, while annuities and pension receipts are taxed; so any lump sum withdrawals need to be taxed if taxation is not to be reduced on defined contribution pensions (Blake, Cannon and Tonks, 2010).
} 
Auerbach, A.J. and Kotlikoff, L.J. (1987) Life Insurance of the Elderly: Its Adequacy and Determinants. In Work, Health and Income Among the Elderly, edited by G. Burtless, Brookings Institution, pp. 229-268.

Auerbach, A.J. and Kotlikoff, L.J. (1989) The Adequacy of Life Insurance Purchases, Journal of Financial Intermediation, vol. 1, no.3, June, pp. 215-241.

Babbel, D.F. and Merrill, C.B. (2007), Rational Decumulation, Working paper, University of Pennsylvania, May.

Bernheim, B.D. (1991) How Strong Are Bequest Motives? Evidence Based on Estimates of the Demand for Life Insurance and Annuities, Journal of Political Economy, Vol. 99, No.5, October, pp. 899-927.

Beshears, J., Choi, J.J., Laibson, D., Madrian, B.C. and Zeldes, S.P. (forthcoming) What makes Annuitization More Appealing? Journal of Public Economics.

Blake, D., Cannon, E. and Tonks, I. (2010) Ending Compulsory Annuitization: What Are the Consequences?, The Pensions Institute.

Blake, D. and Harrison, D. (2008) And Death Shall Have No Dominion: Life Settlements and the Ethics of Profiting from Mortality, The Pensions Institute.

Blake, D. and Harrison, D. (2009) What is a Life Settlement? In Life Markets: Trading Mortality and Longevity Risk with Life Settlements and Linked Securities, edited by V.B. Bhuyan, John Wiley, pp. 11-16.

Braun, A., Gatzert, N. and Schmeiser, H. (2012) Performance and Risks of Open-End Life Settlement Funds, Journal of Risk and Insurance, vol. 79, no. 1, pp. 193-229.

Brown, J.R. (2001) Are the Elderly Really Over-Annuitized? New Evidence on Life Insurance and Bequests. In Themes in the Economics of Aging, edited by D.A. Wise, University of Chicago Press, pp. 91-126.

Brown, J.R. (2002) How Should We Insure Longevity Risk in Pensions and Social Security? In The Future of Social Insurance: Incremental Action or Fundamental Reform?, edited by P. Edelman, D.L. Salisbury, and P.J. Larson, National Academy of Social Insurance, pp. 148-183.

Brown, J.R. (2009) Financial Education and Annuities, OECD Journal: General Papers, no. 20, vol. 2008, issue 3, pp. 173-215.

Brown, J.R., Casey, M.D. and Mitchell, O.S. (2007) Who Values the Social Security Annuity? New Evidence on the Annuity Puzzle, NBER Working paper, NB07-02, December.

Brown, J.R., Kapteyn, A., Luttmer, E.F.P. and Mitchell, O.S. (2013) Complexity as a Barrier to Annuitization: Do Consumers Know How to Value Annuities?, Working paper, Pension Research Council, no. WP2013-01, March.

Brown, J.R. and Warshawsky, M.J. (2012) Longevity-Insured Retirement Distributions: Basic Theories and Institutions. In Retirement Income: Risks and Strategies, edited by M.J. Warshawsky, The MIT Press, pp. $57-83$.

Brown, J.R. and Warshawsky, M.J. (2004) Longevity-Insured Retirement Distributions from Pension Plans: Market and Regulatory Issues. In Private Pensions and Public Policies edited by W.G. Gale, J.B. Shoven and M.J. Warshawsky, Brookings Institution Press, pp. 332-381.

Brown, R.L. and McDaid, J. (2003) Factors Affecting Retirement Mortality, North American Actuarial Journal, vol. 7, no. 2, April, pp. 24-43.

Brown, R.L. and Scahill, P. (2010) Issues in the Issuance of Enhanced Annuities, SEDAP Research Paper no. 265, May, McMaster University.

Browne, S., Milevsky, M.A. and Salisbury, T.S. (2003)Asset Allocation and the Liquidity Premium for Illiquid Annuities, Journal of Risk and Insurance, vol. 70, no. 3, September, pp. 509-526.

Bütler, M. and Ruesch, M. (2007) Annuities in Switzerland, Policy Research Working Paper, World Bank, no, 4438, December.

Bütler, M. and Staubli, S. (2011) Payouts in Switzerland: Explaining Developments in Annuitization. In Securing Lifetime Retirement Income: Global Annuity Markets and Policy, edited by O.S. Mitchell, J. Piggott and N. Takayama, Oxford University Press.

Cannon, E. and Tonks, I. (2004) UK Annuity Rates, Money's Worth and Pension Replacement Ratios 19572002, Geneva Papers on Risk and Insurance, vol. 29, no. 3, July, pp. 394-416.

Cannon, E. and Tonks, I. (2008) Annuity Markets, Oxford University Press, chapter 6.

Cannon, E, and Tonks, I. (2009) Money's Worth of Pension Annuities, Department for Work and Pensions, Research Report no. 563.

Cannon, E. and Tonks, I. (2011) Compulsory and Voluntary Annuities Markets in the UK. In Securing Lifelong Retirement Income: Global Annuity Markets and Policy, edited by O. Mitchell, J. Piggott and N. Takayama, Oxford University Press, pp. 171-194. 
Cawley, J. and Philipson, T. (1999) An Empirical Examination of Information Barriers to Trade in Insurance, American Economic Review, vol. 89, no. 4, September, pp. 827-846.

Chalmers, J. and Reuter, J. (2012) How Do Retirees Value Life Annuities? Evidence from Public Employees, Review of Financial Studies, vol. 25, no. 8, August, pp. 2601-2634.

Charupat, N., Kamstra, M. and Milevsky, M.A. (2012) The Annuity Duration Puzzle, Working paper, York University, March.

Charupat, N. and Milevsky, M.A. (2001) Mortality Swaps and Tax Arbitrage in the Canadian Insurance and Annuity Markets, Journal of Risk and Insurance, vol. 68, no. 2, June, pp. 277-302.

Comyn, R.B. (1834) A Treatise on the Law of Usury, J.S. Littell, London.

Cox, S.H. and Lin, Y. (2007) Natural Hedging of Life and Annuity Mortality Risks, North American Actuarial Journal, vol. 11, no. 3, July, pp. 1-15.

Crawford, R. and Tetlow, G. (2012) Expectations and Experience of Retirement in Defined Contribution Pensions: A Study of Older People in England, Institute for Fiscal Studies, November.

Cutler, D.M., Finkelstein, A. and McGarry, K. (2008) Preference Heterogeneity and Insurance Markets: Explaining a Puzzle of Insurance, American Economic Review, vol. 98, no. 2, May, pp. 157-162.

Davidoff, T., Brown, J.R. and Diamond, P.A. (2005) Annuities and Individual Welfare, American Economic Review, vol. 95, no. 5, December, pp. 1573-1590.

Finkelstein, A. and Poterba, J.M. (2002) Selection Effects in the United Kingdom Individual Annuities Market, Economic Journal, vol. 112, no. 476, January, pp. 28-50.

Finkelstein, A. and Poterba, J. (2004) Adverse Selection in Insurance Markets: Policyholder Evidence from the UK Annuity Market, Journal of Political Economy, vol. 112, no. 1, February, pp. 183-208.

Fitzpatrick, M.D. (2011) How Much Do Public School Teachers Value Their Retirement Benefits?, Working paper, Cornell University, 56 pages.

Fong, J.H.Y. (2011) Beyond Age and Sex: Enhancing Annuity Pricing, Pension Research Council Working Paper 2011-07, University of Pennsylvania, June.

Fong, J.H.Y., Mitchell, O.S. and Koh, B.S.K. (2010) Longevity Risk Management in Singapore's National Pension System, Working paper, Pension Research Council, WP2010-10.

Fong, W.M. (2002) On the Cost of Adverse Selection in Individual Annuity Markets: Evidence from Singapore, Journal of Risk and Insurance, vol. 69, no. 2, June, pp. 193-207.

Friedman, B. and Warshawsky, M. (1990) The Cost of Annuities: Implications for Saving Behaviour and Bequests, Quarterly Journal of Economics, vol. 105, no. 1, February, pp. 135-154.

Gardner, J. and Wadsworth, M. (2004) Who Would Buy an Annuity? An Empirical Investigation, Watson Wyatt Technical Paper Series.

Gatzert, N. (2010) The Secondary Market for Life Insurance in the United Kingdom, Germany and the United States: Comparison and Overview, Risk Management and Insurance Review, vol. 13, no. 2, Fall, pp. 279-301.

Guiso, L. and Sodini, P. (2013) Household Finance: An Emerging Field. In Handbook of the Economics of Finance edited by G.M. Constantinides, M. Harris and R.M. Stulz, vol. 2, part B, Science Direct, pp. 1397-1532.

Gupta, A. and Li, Z. (2007) Integrating Optimal Annuity Planning with Consumption-Investment Selections in Retirement Planning, Insurance: Mathematics and Economics, vol. 41, no. 1, July, pp. 96-110.

Harrison, D., Byrne, A. and Blake, D. (2006) Annuities and Accessibility: How the Industry Can Empower Consumers to Make Rational Choices, The Pensions Institute, March.

He, D. (2009) The Life Insurance Market: Asymmetric Information Revisited, Journal of Public Economics, vol. 93, no. 9-10, October, pp. 1090-1097.

Horneff, W.J. and Maurer, R.H. (2008) Deferred Annuities and Strategic Asset Allocation, Working paper, Michigan Retirement Research Centre, no. 2008-178.

Horneff, W.J., Maurer, R.H., Mitchell, O.S. and Dus, I. (2008) Following the Rules: Integrating Asset Allocation and Annuitization in Retirement Portfolios, Insurance: Mathematics and Economics, vol. 42, no. 1, February, pp. 396-408.

Horneff, W.J., Maurer, R.H., Mitchell, O.S. and Stamos, M.Z.(2008) Asset Allocation and Location Over the Life Cycle with Investment-Linked Survival-Contingent Payouts, Journal of Banking and Finance, vol. 33, no. 9, September, pp. 1688-1699.

Horneff, W.J., Maurer, R.H., Mitchell, O.S. and Stamos, M.Z. (2010) Variable Payout Annuities and Dynamic Portfolio Choice in Retirement, Journal of Pension Economics and Finance, vol. 9, no. 2, April, pp. 
163-183.

Horneff, W.J., Maurer, R.H., and Rogalla, R. (2010) Dynamic Portfolio Choice with Deferred Annuities, Journal of Banking and Finance, vol. 34, no. 11, November, pp. 2652-2664.

Horneff, W.J., Maurer, R.H., and Stamos, M.Z.(2008a) Life-Cycle Asset Allocation with Annuity Markets, Journal of Economic Dynamics and Control, vol. 32, no. 11, November, pp. 3590-3612.

Horneff, W.J., Maurer, R.H., and Stamos, M.Z.(2008b) Optimal Gradual Annuitization: Quantifying the Costs of Switching to Annuities, Journal of Risk and Insurance, vol. 75, no. 4, December, pp. 1019-1038.

Huang, H. and Milevsky, M.A. (2008) Portfolio Choice and Mortality-Contingent Claims: The General HARA Case, Journal of Banking and Finance, vol. 32, no. 11, November, pp. 2444-2452.

Hueler, K. and Rappaport, A. (2012) The Role of Guidance in the Annuity Decision Making Process, Working paper, Pension Research Council, WP2012-11, September.

Idler, E.L. and Benyamini, Y. (1997) Self-Rated Health and Mortality: A Review of Twenty-Seven Community Studies, Journal of Health and Social Behaviour, vol. 38, no. 1, March, pp. 21-37.

James, E. and Sane, R. (2003) The Annuity Market in India: Do Consumers Get Their Money's Worth? What Are the Key Public Policy Issues? In Rethinking Pension Provision for India edited by A. Bordia and G. Bhardwaj, Tata McGraw-Hill India.

James, E. and Song, X. (2001) Annuities Markets Around the World: Money's Worth and Risk Intermediation, Woking paper no. 16/01, Centre for Research on Pensions, December.

James, E. and Vittas, D. (2000) Annuity Markets in Comparative Perspective: Do Consumers Get Their Money's Worth?, World Bank, Development Research Group, Policy Research Working Paper, No. 2493, November.

Kapur, S. and Orszag, J.M. (1999) A Portfolio Approach to Investment and Annuitization During Retirement, Birkbeck Working Paper no 15.

Kaschützke, B. and Maurer, R. (2011) The Private Life Annuity Market in Germany: Products and Money's Worth Ratios. In Securing Lifelong Retirement Income: Global Annuity Markets and Policy edited by O.S. Mitchell, J. Piggott and N. Takayama, Oxford University Press, pp. 131-158.

Keilman, N. (2007) UK National Population Projections in Perspective: How Successful Compared to Those in Other European Countries?, Population Trends, Vol. 129, Autumn, pp. 20-30.

McCarthy, D. and Mitchell, O.S. (2010) International Adverse Selection in Life Insurance and Annuities. In Ageing in Advanced Industrial States edited by S. Tuljapurkar, N. Ogawa and A.H. Gauthier, Springer, pp. 119-135.

MGM Advantage (2009) Launch of MGM Advantage Annuity Index Reveals Average Difference of 22\% Between Standard and Enhanced Annuities. Download from:http://www.mgmadvantage.com/homepage/media-centre/press-releases/press-release-14.html

Milevsky, M. A. (2006) The Calculus of Retirement Income: Financial Models for Pension Annuities and Life Insurance, Cambridge University Press.

Milevsky, M.A. and Shao, L. (2011) Annuities and their Derivatives: the Recent Canadian Experience. In Securing Lifetime Retirement Income: Global Annuity Markets and Policy, edited by O.S. Mitchell, J. Piggott and N. Takayama, Oxford University Press.

Milevsky, M.A, and Young, V.R. (2007) Annuitization and Asset Allocation, Journal of Economic Dynamics and Control, vol. 31, no. 9, September, pp. 3138-3177.

Mitchell, O.S. (2002) Developments in Decumulation: The Role of Annuity Products in Financing Retirement. In Ageing, Financial Markets and Monetary Policy, edited by A.J. Auerbach and H. Herrmann, Springer, pp. 97-138.

Mitchell, O.S., Poterba, J.M., Warshawsky, M.J. and Brown, J.R. (1999). New Evidence on the Money's Worth of Individual Annuities, American Economic Review, vol. 89, no. 5, December, pp. 1299-1318.

Mitchell, O.S. and McCarthy, D. (2002) Estimating International Adverse Selection in Annuities, North American Actuarial Journal, vol. 6, no. 4, October, pp. 38-54.

Murthi, M., Orszag, M. and Orszag, P.R. (2000) The Value for Money of Annuities in the UK: Theory, Experience and Policy, Journal of Pensions Management, May.

Neuberger, A. (2003) Annuities and the Optimal Investment Decision, Working paper London Business School, May.

OECD (2012) Pension Markets in Focus, no. 9, September, Download from:http://www.oecd.org/insurance/privatepensions/pensionmarketsinfocus.htm

Ogborn, M.E. and Wallas, G.E. (1955) Deferred Annuities with Participation in Profits, Journal of the Institute 
of Actuaries, vol. 81, April, pp. 261-299.

Pang, G. and Warshawsky, M. (2010) Optimizing the Equity-Bond-Annuity Portfolio in Retirement: The Impact of Uncertain Health Expenses, Insurance: Mathematics and Economics, vol. 46, no. 1, January, pp. 198-209.

Park, Y. (2011) Retirement Income Adequacy with Immediate and Longevity Annuities, EBRI Issue Brief, no. 357. May, pp. 1-34.

Peijnenburg, K., Nijman, T. and Werker, B.J.M. (2011) Health Cost Risk: A Potential Solution to the Annuity Puzzle, Working paper, CentER, Tilburg University, April.

Pensions Board (2006) Report of the Member Options Working Party, Actuarial Profession, December. Download from:- www.actuaries.org.uk/.../memberoptionsworkingparty2006report.pdf

Pension Regulator (2013) Pension Liberation Fraud. Download from:http://www.thepensionsregulator.gov.uk/regulate-and-enforce/pension-liberation.aspx

Promislow, S.D. (2011) Fundamentals of Actuarial Mathematics, Wiley, Second edition.

Rocha, R. and Thorburn, C. (2007) Developing Annuity Markets: The Experience of Chile, The World Bank, Annex 1, pp. 149-180.

Shaw, C. (2007) Fifty Years of United Kingdom National Population Projections: How Accurate Have They Been?, Population Trends, vol. 128, Summer, pp. 8-23.

Sheshinski, E. (2010) Refundable Annuities (Annuity Options), Journal of Public Economic Theory, vol. 12, no. 1, February, pp. 7-21.

Sinclair, S.H. and Smetters, K.A. (2004) Health Shocks and the Demand for Annuities, Technical Paper Series, Congressional Budget Office, July.

Thorburn, C., Rocha, R. and Morales, M, (2007) An Analysis of Money's Worth Ratios in Chile, Journal of Pension Economics and Finance, vol. 6, no. 3, November, pp. 287-312.

Turra, C.M. and Mitchell, O.S. (2008) The Impact of Health Status and Out-of-Pocket Medical Expenditures on Annuity Valuation. In Recalibrating Retirement Spending and Saving edited by J. Ameriks and O.S. Mitchell, Oxford University Press, pp. 227-250.

Velde, F.R. and Weir, D.R. (1992) The Financial Market and Government Debt Policy in France, 1746-1793, Journal of Economic History, vol. 52, no. 1, March, pp. 1-39.

Von Gaudecker, H.M. and Weber, C. (2004) Surprises in a Growing Market Niche: An Evaluation of the German Private Life Annuities Market, Geneva Papers on Risk and Insurance, vol. 29, no. 3, July, pp. 394-416.

Walliser, J. (2000) Adverse Selection in the Annuities Market and the Impact of Privatizing Social Security, Scandinavian Journal of Economics, vol. 102, no. 3, September, pp. 373-393.

Wang, T. and Young, V.R. (2012a) Optimal Commutable Annuities to Minimise the Probability of Lifetime Ruin, Insurance: Mathematics and Economics, vol. 50, no. 1, January, pp. 200-216.

Wang, T. and Young, V.R. (2012b) Maximizing the Utility of Consumption with Commutable Life Annuities, Insurance: Mathematics and Economics, vol. 51, no. 2, September, pp. 352-369.

Yaari, M.E. (1965) Uncertain Lifetime, Life Insurance, and the Theory of the Consumer, Review of Economic Studies, vol. 32, no. 2, April, pp. 137-150.

Zeng, L. (2010) Optimal Consumption and Portfolio Choice for Retirees, Working paper, Illinois Institute of Technology.

\section{Appendix 1: Example 1 - Offsetting an Annuity}

Example $1^{23}$. Two years ago Orsino Thruston bought an annuity for $£ 100,008\left(V_{65}{ }^{*}\right)$. Consistent with equation (1), this yields an annuity payment of $£ 8,628$ per year $(A)$ until his death. At the age of 67 he now wishes to offset this annuity, and so he uses equation (1) to compute the current price of an annuity of $£ 8,628$ p.a. at $£ 93,641$. Setting $V_{67}{ }^{*}=X^{*}$, he borrows $£ 93,641\left(X^{*}\right)$ at a fixed rate of $4 \%(r)$. This loan

\footnotetext{
${ }^{23}$ This example is based on a life annuity for a male aged 65 using English actuarial tables for 2007-2009 from the Office of National Statistics. There are no survivor benefits or other complications.
} 
requires interest payments of $(£ 93,641 \times 0.04)=£ 3,746$ per year, leaving a net cash inflow of $£ 4,882$ per year. Orsino uses this $£ 4,882$ p.a. to pay the annual premiums (computed using equation (2) or (4)) on a life insurance policy on his life worth $£ 93,641$. For simplicity and brevity, it is assumed that Orsino dies at the end of the fourth year. So Orsino has effectively liquidated his annuity now for $£ 93,641$, its actuarially fair value.

Table A1 shows that, by surviving until year two, Orsino has benefited from a mortality credit with a present value of $£ 2,841$. This is the difference between investing the $£ 100,008$ in bonds and in an annuity. Investment in bonds at $4 \%$ would mean that in year two he would have a bond worth $£ 100,008$, together with two year's interest worth $(£ 4,000 \times 1.04+£ 4,000)=£ 8,160$ : a total of $£ 108,168$. Investment in the annuity generates two annuity payments worth $(£ 8,628 \times 1.04+£ 8,628)=£ 17,600$ in year two, plus an annuity with an actuarially fair price of $£ 93,641$; which gives a total of $£ 111,241$. Therefore investment in the annuity produces a gain due to the mortality credit of $(£ 111,241-£ 108,168)=£ 3,073$ in year two, which has a present value in year zero of $£ 2,841$.

Year Transaction

Cost of annuity

Annuity

Annuity

Borrow

Insure life for $£ 93,641$

Mortality Credit

Totals

3 Annuity

3 Interest payments (£93,641@4\%)

3 Life insurance premia

4 Annuity

$4 \quad$ Interest payments $(£ 93,641 @ 4 \%)$

$4 \quad$ Life insurance premia

$4 \quad$ Life insurance claim

4 Repay loan

Totals
Undiscounted Cash Flows Discounted Cash Flows

\begin{tabular}{rrrr} 
Inflows & Outflows & \multicolumn{1}{c}{ Inflows } & Outflows \\
- & $£ 100,008$ & - & $£ 100,008$ \\
$£ 8,628$ & - & $£ 8,296$ & - \\
$£ 8,628$ & - & $£ 7,977$ & - \\
$£ 93,641$ & - & $£ 86,576$ & - \\
- & - & - & - \\
- & - & $\underline{£ 102,849}$ & $\underline{£ 102,844}$ \\
& & $\underline{\underline{£ 102,849}}$
\end{tabular}

$$
£ 8,628
$$

$\begin{array}{ll}- & £ 3,746 \\ - & £ 4,882\end{array}$

$£ 8,628$

$£ 3,746$

$£ 4,882$

$£ 93,641$

$£ 93,641$
$£ 7,670$

$£ 3,330$

$£ 4,340$

$£ 7,375$

$£ 3,202$

$£ 4,173$

$£ 80,045$

$\frac{-}{£ 95,090}$

$£ 80,045$

$£ 95,090$

Table A1: Example of Offsetting an Annuity

This example shows the cash flows from buying an annuity, and then offsetting it two years later by borrowing the current price of the annuity and insuring the annuitant's life for the same amount. Subsequent net cash flows are zero. On death (two years later) the life insurance payment is used to repay the loan. 
Example 2. Suppose that annuities have a load factor $(w)$ equal to $5 \%$ of the actuarially fair price. The initial cost in year zero of an annuity of $£ 8,628$ on the life of Orsino Thruston rises by $5 \%$ to $£ 105,008$. In year two the current price of this annuity of $£ 8,628$ p.a. is $5 \%$ higher at $£ 98,323$, rather than $£ 93,641$. Due to the higher price of the annuity, an offset by Orsino no longer gives him the actuarially fair value of the annuity. He can still borrow $£ 93,641$, pay interest of $£ 3,746$ p..a. and $£ 4,882$ p.a. in life insurance premiums on a policy worth $£ 93,641$ and so meet equation (4). Orsino has effectively liquidated (sold) his annuity at a price that is $(£ 98,323-£ 93,641)=£ 4,682$ below the current market price. Since he initially paid $£ 5,000$ above its actuarially fair value, this reduction in value was created when the annuity was purchased in year zero ${ }^{24}$.

Example 3. If life insurance also has a load factor $(p)$, in addition to the annuity load factor of $5 \%$, the size of Orsino's loan is further reduced. Suppose the insurance premium has a load factor of $5 \%$ of its actuarially fair price, Orsino can only afford to insure his life for $£ 91,064$, rather than $£ 93,641$; paying $£ 4,985$ p.a. in premiums and $£ 3,643$ p.a. in interest on a loan of $£ 91,064$. So the life insurance load factor means that Orsino's loss, relative to actuarially fair values, in conjunction with the annuity load factor, has increased by $£ 2,577$ to $£ 7,259$.

\section{Appendix 3: Examples 4 and 5 - Arbitrage With and Without Load Factors}

Example 4. Suppose that Orsino Thruston is offered an annuity of $£ 8,628$ p.a. at a price of only $£ 88,000$, when its actuarially fair price is $£ 93,641$, which implies a negative load factor of $6.0 \%$. Life insurance is being sold at its actuarially fair price. He simultaneously buys this annuity, borrows $£ 93,641$ at $4 \%$ (or $£ 3,746$ p.a.) and insures his life for $£ 93,641$ at an annual cost of $£ 4,882$. Therefore he has made an instant arbitrage profit of $(£ 93,641-£ 88,000)=£ 5,641$ which is immediately available to him in cash.

Example 5. Suppose that, as in example 4, Orsino is offered an annuity of $£ 8,628$ p.a. at a price of $£ 88,000$, when its actuarially fair price is $£ 93,641$. Life assurance is now overpriced by $5 \%$, and using equation (5) this corresponds to a loan of $£ 91,064$. Orsino can make an instant arbitrage profit of ( $£ 91,064-£ 88,000)=£ 3,064$ by simultaneously buying the annuity, insuring his life for $£ 91,064$, and borrowing $£ 91,064$. He pays interest of $£ 3,643$ p.a. and life insurance premia of $£ 4,985$ p.a. So, as table

\footnotetext{
${ }^{24}$ This loss can also be computed from equation (6).
} 
A2 shows, even when life insurance is sold at 5\% above its actuarially fair price, arbitrage can still be profitable, provided annuities are underpriced. For simplicity, Orsino is assumed to die after two years.

\begin{tabular}{|c|c|c|c|c|c|}
\hline \multirow[t]{2}{*}{ Year } & \multirow[t]{2}{*}{ Transaction } & \multicolumn{2}{|c|}{ Undiscounted Cash Flows } & \multicolumn{2}{|c|}{ Discounted Cash Flows } \\
\hline & & Inflows & Outflows & Inflows & Outflows \\
\hline 0 & Cost of annuity & - & $£ 88,000$ & - & $£ 88,000$ \\
\hline 0 & Borrow & $£ 91,064$ & . & $£ 91,064$ & \\
\hline 0 & Insure life for $£ 91,064$ & - & - & - & - \\
\hline 0 & Profit & - & - & - & $£ 3,064$ \\
\hline Totals & & & & $\overline{£ 91,064}$ & $\underline{£ 91,064}$ \\
\hline 1 & Annuity & $£ 8,628$ & - & $£ 8,296$ & - \\
\hline 1 & Interest payments (£91,068@4\%) & - & $£ 3,643$ & - & $£ 3,503$ \\
\hline 1 & Life insurance premia & - & $£ 4,985$ & - & $£ 4,793$ \\
\hline 2 & Annuity & $£ 8,628$ & - & $£ 7,977$ & - \\
\hline 2 & Interest payments (£91,068@4\%) & - & $£ 3,643$ & - & $£ 3,368$ \\
\hline 2 & Life insurance premia & - & $£ 4,985$ & & $£ 4,609$ \\
\hline 2 & Life insurance claim & $£ 91,064$ & - & $£ 84,194$ & - \\
\hline 2 & Repay loan & - & $£ 91,064$ & - & $£ 84,194$ \\
\hline Totals & & & & $\overline{£ 100,467}$ & $£ 100,467$ \\
\hline
\end{tabular}

Table A2: Example of Arbitrage of an Annuity Underpricing with a Life Insurance Load Factor The arbitrageur buys an underpriced annuity and an overpriced life insurance policy for an amount given by equation (5), and borrows the same amount. This generates an immediate arbitrage profit.

\section{Appendix 4: Example 6 - Speculation on an Increase in Longevity}

Example 6. Continuing with the Orsino Thruston example, suppose that over the next two years Orsino predicts his expected longevity to increase by two years. So he buys an annuity now, based on the life insurance company's current assessment of his longevity. This actuarially fair annuity is for $£ 8,628$ p.a. at a price of $£ 100,008$. After two years his expected longevity has, as he predicted, increased by two years, so that the price of the annuity of $£ 8,628$ on his life is still $£ 100,008$. Orsino can now offset the original annuity by insuring his life for $£ 100,008$ at a cost of $£ 4,628$ p.a. (using the new longevity expectations and assuming no load factors), and borrowing $£ 100,008$ at a cost of $£ 4,000$ p.a. Table A3 shows that this generates cash flows with a present value of $£ 8,728$ in year zero. The mortality credit (see table A1) accounts for $£ 2,841$ of this gain (his reward for surviving for two years to reach the age of 67), leaving a profit due to longevity speculation with a present value of $£ 5,887$. All of this increase in Orsino's wealth is available to him in year 2, i.e. $£ 5,887(1.04)^{2}=£ 6,367$. 
0 Cost of annuity

1 Annuity

0 Open an interest rate hedge

$\begin{array}{rr}\text { Inflows } & \text { Outflows } \\ - & £ 100,008 \\ - & - \\ £ 8,628 & - \\ £ 8,628 & - \\ £ 100,008 & - \\ - & - \\ - & - \\ - & - \\ - & -\end{array}$

$£ 8,628$

Annuity

Interest payments (£100,008@4\%)

Life insurance premia

Annuity

Interest payments (£100,008@4\%)

Life insurance premia

Life insurance claim

Repay loan

$\begin{array}{rr}£ 8,628 & - \\ - & £ 4,000 \\ - & £ 4,628 \\ £ 8,628 & - \\ - & £ 4,000 \\ - & £ 4,628 \\ £ 100,008 & - \\ - & £ 100,008\end{array}$

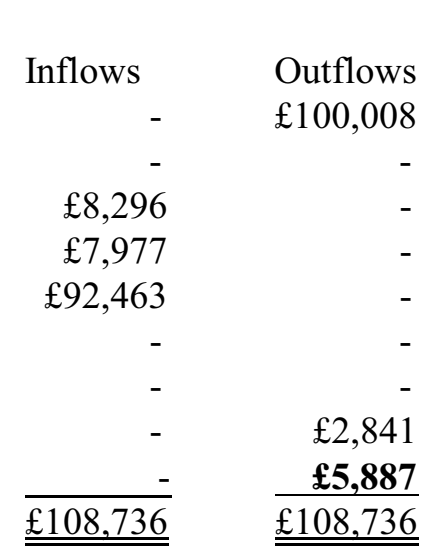

$£ 7,670$

$£ 3,556$

$£ 4,114$

$£ 7,375$

$£ 3,419$

$£ 3,956$

$£ 85,487$

$£ 85,487$

Totals

Table A3: Example of Speculating on an Increase in Expected Longevity

The speculator buys an annuity and hedges the interest rate risk. Two years later, when their longevity as assessed by an insurance company has increased by two years, they insure their life for the current value of the annuity, borrow the same amount, and unwind the interest rate hedge. This generates a mortality credit, and a speculative profit in year two. Subsequent net cash flows are zero.

\section{Appendix 5: Example 7 - Speculation on a Decrease in Longevity}

Example 7. Continuing with the Orsino Thruston example, and assuming that in year two the price of an annuity of $£ 8,628$ p.a. is $£ 88,000$, rather than the previously actuarially fair price of $£ 93,641$. Just as a long position in an annuity generates a mortality credit, holding a short position in an annuity produces a negative mortality credit. Orsino suffers the loss of a mortality credit with a value of $£ 2,841$ in year zero, due to delaying the purchase of the annuity by two years. Table A4 shows that the decrease in expected longevity and the resulting drop in annuity prices means that Orsino makes a profit in year two, with a present value of $£ 5,215$ (or $£ 5,215(1.04)^{2}=£ 5,641$ in year two). 
Year Transaction

0 Borrow

$0 \quad$ Insure life for $£ 100,008$

$0 \quad$ Open an interest rate hedge

1 Interest payments (£100,008@4\%)

1 Life insurance premia

2 Interest payments ( $£ 100,008 @ 4 \%)$

2 Life insurance premia

2 Cost of annuity

2 Close the interest rate hedge

Mortality Credit (see table A1)

Profit

Totals

$\begin{array}{ll}3 & \text { Annuity } \\ 3 & \text { Interest payments }(£ 100,008 @ 4 \%) \\ 3 & \text { Life insurance premia } \\ 4 & \text { Annuity } \\ 4 & \text { Interest payments }(£ 100,008 @ 4 \%) \\ 4 & \text { Life insurance premia } \\ 4 & \text { Life insurance claim } \\ 4 & \text { Repay loan }\end{array}$

Undiscounted Cash Flows

Discounted Cash Flows

\begin{tabular}{|c|c|c|c|}
\hline Inflows & Outflows & Inflows & Outflows \\
\hline$£ 100,008$ & - & $£ 100,008$ & - \\
\hline - & - & - & . \\
\hline - & - & - & - \\
\hline - & $£ 4,000$ & - & $£ 3,846$ \\
\hline - & $£ 4,628$ & - & $£ 4,450$ \\
\hline - & $£ 4,000$ & - & $£ 3,698$ \\
\hline - & $£ 4,628$ & - & $£ 4,279$ \\
\hline - & $£ 88,000$ & - & $£ 81,361$ \\
\hline - & 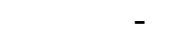 & - & - \\
\hline - & - & $£ 2,841$ & - \\
\hline - & - & - & $£ 5,215$ \\
\hline - & - & $\overline{£ 102,849}$ & $£ 102,849$ \\
\hline$£ 8,628$ & - & $£ 7,670$ & - \\
\hline - & $£ 4,000$ & - & $£ 3,556$ \\
\hline - & $£ 4,628$ & - & $£ 4,114$ \\
\hline$£ 8,628$ & - & $£ 7,375$ & - \\
\hline- & $£ 4,000$ & - & $£ 3,419$ \\
\hline - & $£ 4,628$ & - & $£ 3,956$ \\
\hline$£ 100,008$ & - & $£ 85,487$ & - \\
\hline- & $£ 100,008$ & $\frac{-}{£ 100,532}$ & $\frac{£ 85,487}{£ 100,532}$ \\
\hline
\end{tabular}

Table A4: Example of Speculating on a Decrease in Expected Longevity

The speculator borrows the current value of an annuity, insures their life for the same amount, and hedges the interest rate risk. After two years their longevity, as assessed by an insurance company, has decreased by two years, and they buy an annuity and close out the interest rate hedge. This generates a profit in year two, less the mortality credit. Subsequent net cash flows are zero. 